\title{
Study Of Branchless Banking Business Model
}

\author{
Tetty Yuliaty \\ Faculty of Economic and Business \\ Universitas Sumatera Utara \\ tettyjuliaty@gmail.com \\ Muslim Marpaung \\ Politeknik Negeri Medan \\ Oenk569@yahoo.com
}

\author{
M. Fauzan Azhmy \\ STIE Harapan \\ azgmeyfauzan@gmail.com \\ Hendri Tanjung \\ UIKA Bogor \\ hendri.tanjung@gmail.com
}

\begin{abstract}
Branchless banking has the potential to revolutionize payment systems in emerging markets, to extend formal financial services to unbanked and to provide platform to connect MSMEs to the global economy. Three distinct models have been identified there are Non-bank/ Telecommunications company (Telco)-led, Bank-led, and "hybrid." This research is to study the concept and the business model on the branchless banking and their role in achieving of those matters. The objective of this study is to understand the benefits of the branchless banking and its the business model. In which is the best business model on the branchless banking. A study of a number of research papers, articles in magazine and other publication including internet was used to research this paper, and to use primary data as necessary and secondary in the implementation. Data collection method in this research is documentation study, Direct observation, Indepth interview, Open Question. and provide a questionnaire to informants and other sources. Qualitative Data Analysis Method used in this research is successive approximation method. The results of this study indicate that the presence of Branchless banking is not so well known by the people of Medan, only about 21.9\% of people who know Branchless banking. From this result, the application of branchless banking is considered too early. Currently, only 4 Banks approved by the Financial Services Authority to conduct Branchless Banking. They are Bank Mandiri, BRI, BTPN, and BCA, among the above 4 Banks, BTPN agents are the most widely known bank agent and have very many outlets in Medan city. Of the three Branchless Banking business models launched in 2013, the business model currently implemented is Bank Led, which is the bank responsible for conducting banking services from the beginning to the end, the lack of socialization and education makes public awareness for the bank is still very minimal.
\end{abstract}

Keyword-branchless banking; financial inclusion; mobile banking; internet banking; agent banking

\section{INTRODUCTION}

The world of banking is now more active to improve its services to the wider community. Bank that used to be silent on the spot waitIng for customers to come to open their accounts. Now, instead of banking is active to pick up the ball looking for customers. As its development is increasingly unstoppable due to the latest technological advances make it more freely serving its customers in various ways. Including the most sophisticated, recently the latest innovation in the banking world called Branchless Banking. Branchless Banking is a banking innovation in reaching its financial services to customers without going through the physical office of the bank but only utilizing the services of agents or information and communication technology. Also, banking financial services can be done anywhere and anytime.
Examples of the most common Branchless Banking services are mobile banking, internet banking, electronic money, mobile money, and more. Branchless Banking (BB) may also be the utilization of agents and information and communication technology for the provision of banking financial services.

Yenny, branchless banking as a form of distribution or financial services to communities outside traditional bank branches using information and communication technology (ICT) [1].

The launch of Branchless Banking is very much welcomed by the government because the government realizes that Indonesia is one of the countries with low financial literacy condition. One of the factors that resulted in the low literacy is the lack of enthusiasm for the public on financial services products. This can be due to the geographical conditions in some areas in Indonesia that are difficult to reach out by the communities

Not only that, majority of Indonesian people are from the middle to lower economic class have the perception that bank is not suitable for them. Those people think most of them still have the mindset that banking is complicated and less practical Also, the obligation to fill out the administrative form and costs. They think are costs that should not be spent. In addition, the factor from the community is low accessibility of financial services is also caused by the Financial Institution. Financial institutions are faced with a relatively large cost requirement to build branch network in the remote areas. This limitation of regional coverage also contributes to the low accessibility of financial services to the community in an inclusive manner.

To overcome some of the above obstacles, the idea of branchless banking emerged to bridge these two constraints. Branchless banking (BB) is a banking service without going through a physical bank office. Based on efforts to realize finance inclusively in order to achieve financial system stability strengthening. It is just that the branchless banking business model has many obstacles, from the high risk of the banking agents, the network facilities that become constraints and the convenience is still not very convincing and also the infrastructure and others matter.

So, even though it has been tested by Bank Indonesia in May 2013, but the echo has not been so heard, both by banking customers who implement it and the general public. Only a small proportion of customers from related bank has done this service knowing it. Though not a few customers who have understood this Branchless Banking technology tool, but few who use it or transfer financial transactions to this supersophisticated service, whether mobile banking services, internet banking, electronic money, mobile money, and others. Yet based on a survey of US Census Bureau, active mobile phone users in Indonesia amounted to about 281 million users 
or larger than the population of Indonesia which amounted to about 250 million people. Compare this with the number of people who have an active account at the bank based on a World Bank survey that is only in the range of $20 \%$ of the population over 15 years. In addition, based on the Nielsen survey in 2013, Indonesia became one of the developing countries with the largest smartphone penetration which reached $23 \%$ or doubled from the previous year which was only at $12 \%$ level. The penetration rate is superior compared to India which only reached $18 \%$ and Philippines $15 \%$. Although still under Malaysia reaching 80\%, Thailand 49\% and China $71 \%$, smart phone penetration growth in Indonesia Indonesia is relatively fast, even Frost \& Sullivan survey projects smart phone penetration will be $50 \%$ by 2015 . In fact, this comes up with a question Which is deep enough against the business model applied in branchless banking.

Added to the high level of mobile phone penetration in Indonesia and supported by the potential income of the community is a good prospect for the improvement of inclusive finance through branchless banking. But the fact is until now its development has not been so visible; How is the most appropriate Commercial Model to be applied in the branchless Banking. Research objectives are To know the business model applied in branchless banking. Moreover, To know the best business model applied in branchless banking.

\section{LITERATURE REVIEW}

\section{A. Branchless Banking}

Branchless Banking which is one of the banking distribution strategies that provide financial services without relying on the existence of a bank branch office. Branchless Banking is a distribution network used to provide financial services outside branch offices of bank through technology and alternative networks to be cost-effective, efficient and in safe and comfortable conditions. In banking transactions do not depend on the existence of bank offices, because services and financial activities can be done only by using mobile phones or other forms.

According to Yusharto, Branchless Banking is a banking service without the need to open branch offices. The goal is to reduce the cost of banking services. The expansion of the banking network requires no small cost to reach remote locations in the country. Branchless Banking is one of the potential approaches that are non-conventional, this is because our banking is still conventional [2].

Branchless banking represents a new distribution channel that allows financial institutions and other commercial actors to offer financial services outside traditional bank premises [3].

Khanan stated, Branchless banking is bank services without branch offices, allowing the public to conduct banking transactions without need to go to a branch office with agent brokers [4].

The presence of agents in branchless banking activities as an effort to improve the function of banking intermediation, especially for the less fortunate and people living in remote areas will certainly increase the risk exposure of banks [5]. Assisted banking industry by a scattered bank agent some areas. In other words an agent here as a bridging party between customers with the bank [6].

Branchless Banking has a broader innovative meaning that is in relation to boosting Indonesia's economic growth and also maintaining the stability of the financial system by increasing public access to banking financial services or known as inclusive finance. So, with the access society to the banking financial services, are expected to improve the welfare of the community which in turn can encourage economic growth and simultaneously maintain the stability of the financial system. Inclusive finance means on how the formal financial services can be accessed by all rank of society whoever and wherever they are.

\section{B. Branchless Banking Business Model}

The business model of Branchless Banking is the role of agent / third party which is an extension of the provider of financial services. The role of this agent may be either an individual or a company. In reality the role of agents in remote areas can be small stalls, coffee shops, post offices, or others. So, someone who has not been allowed to open a savings account just sign up to the agent. Bank Indonesia [7].

There are several business models that can be implemented in the implementation of Branchless Banking:

1. Bank Led is a bank responsible for conducting banking services activities from beginning to end,

2. Telco Led is a telecommunication company responsible for transfer activities from beginning to end,

3. Hybrid is a combination of both. Products that may be used include products issued by Bank and/or Telco that are e-money. Furthermore, products issued by the Bank in the form of savings products are free of administrative fees, given interest, products, or e-banking activities, and microcredit disbursement.

\section{MATERIALS AND METHODS}

The type of research that will be used in this research is qualitative descriptive research. According Hidayat Syah, descriptive research is a research method used to find the widest knowledge of the object of research at a given time [8]. Moleong, says that the principle of qualitative research is finding theory and data. The role of a new theory or verification of a new theory will be evident as this data analysation begins. This type is used for qualitative research features such as Current Problems, Holistic, Bending and Open Research Design [9].

The subjects in this study are the related parties such as banking experts, banking agents, customers and other parties that are related to this research'. Also, to complement and refine this research will be sought more information about branchless banking from the informants or respondents who have competence in their field, especially in the field of the latest banking. The location of this research is in Medan, precisely from several public and private Bank that have implemented branchless banking system such as BRI, CIMB Niaga, Mandiri, and others.

\section{A. Statistical Analysis}

There are two kinds of data that is primary data and secondary data. In this qualitative research used various methods of data collection, and documentation studies will be a priority in this study. Moleong in Herdiansyah, presents two forms of documents that can be used as material in the study documentation : daily documents (diaries), personal letters, and autobiographies and official documents of internal documents and external documents [10]. In this research used data collection method as follows : Direct observation (on Bank environment and social environment of sample) that is direct observation done on subject There are two ways used in 
conducting interviews are face to face interview and via telephone [11]. But then along with the times, then the interview can also be done through internet media such as email. Casual conversation/ spontaneous, Open Question, by giving questionnaire to other Source informants.

Informants and respondents are two different things where the informant is an individual who has the expertise and the best understanding of certain issues so that the informant here is a resource, while the respondent is the individual who the interviewer wants to know information about himself/herself from the respondent such as his/her stance, As well as his views on specific issues. In this case are the parties involved in this research such as banking, banking agents, or customers.

\section{B. Qualitative Research Data Analysis Technique}

Qualitative Data Analysis according Bogdan \& biklen, is a work done by working data, organizing data, sorting it into manageable units, sensing it, searching, finding what is important, learn and deciding what can being publicized to others [12].

Validity and Data Trust and Qualitative Data Analysis Model. Qualitative Data Analysis Method. According to Nueman as quoted in Kholil, there are three ways in the research, but that is called one way : Successive approximation method, Starting from research and assumption about concept. Researchers collect additional data to solve unanswered issues so that data is more accurate [13].

\section{RESULTS AND DISCUSSION}

The research was conducted through in-depth interviews to informants consisting of the Financial Services Authority, Bank Indonesia, and Bank BTPN and then the banking agents and bank customers concerned. From the results of this study it is known that as many as 210 questionnaires that have been spread in 6 different locations in several sub-districts in Medan with various professions, through direct observation on the application of Branchless Banking business model, conducted by banking agents and banks, see on how these banking agents conduct account opening or deposit transactions to their customers. To complete the research data by doing casual conservation.

Branchless Banking services implemented in Indonesia, is a non-conventional breakthrough in which in some countries such as Kenya-Africa and Mexico have successfully implemented it. This banking service does provide a better prospect in the future to see the development of the telecommunications industry that has been developing for the last 20 years in Indonesia already has penetration reaching 250 million subscribers in 2011. This is quite promising considering the media used in transactions through Branchless Banking is a mobile phone or Mobile. So it is quite easy to do by the community. But it seems that in launching this product the government is still halfhearted, where the program should be able to appreciate the wider community. From the results of research conducted with the spread of questionnaires on the existence of Branchless Banking, it turns out this service is still not so responded by the community, including the lack of people who have an account at the Bank. Society still does not feel important that being a bankable society will give more value. The lack of bankable community is not only caused by the awareness of the public for the bank is very minimize, but also the lack of information and socialization to make people not interested in doing transactions in the Bank.

The survey results show that only $21.9 \%$ are aware of branchless banking while $78.1 \%$ are completely unaware of this service. Moreover, interestingly, many bank operators themselves do not know this service. From $21.9 \%$ of respondents who know this product, because there is a banking agent nearby at his residence, so, the existence of banking agents around the settlement turned out to be quite effective to introduce branchless banking community just is not so high in using it. By looking at this fact and adding other obstacles, let alone the lack of enthusiasm of the community using this service, as if the government is too early to force this service launched because many people themselves are not familiar with this service. It should be socialization or education to the community must be done before, not just released as it is today, so that impressed "redundant" because the cost is not small. Although the role of OJK to promote Branchless banking is very good, but OJK can not be burdened with this responsibility. With limited funds and personnel of course OJK will not be able to serve the community alone.

Not to mention the lack of awareness of the community to the bank to question whether the service is feasible to be implemented at this time, plus infrastructure is not adequate and often problematic. How the readiness of the organizing bank, it seems the government needs to evaluate it, considering the bank's own closure, and the absence of obligations from the organizing bank to ask all personnel to inform about this service either to the community or its own customers, and the lack of other media to be able to introduce the kites of this bank widely. Is not there many ways to introduce a product or service bank without having to speak directly on the day-to-day tasks. Not many Banks can immediately realize the wishes of the government because it requires commitment, integrity and sacrifices are not small to succeed the program.

With the results of the above answers can be seen that Branchless Banking banking service is not so popular in the city of Medan. Though since 2013 this service has been launched by the government even though it is just an introduction and new effective when Bank Indonesia issued a regulation on banking services on this one. Now Branchless Banking is no longer under the supervision of Bank Indonesia, as effective since December 2014, the Financial Services Authority has taken over the supervision of financial institutions. Including making regulations related to the services or products of the Bank Branchless Banking now has a diverse name from UPLK and it has been called "Laku Pandai."

With the results of the above answers can be seen that Branchless Banking banking service is not so popular in the city of Medan. Though since 2013 this service has been launched by the government even though it is just an introduction and new effective when Bank Indonesia issued a regulation on banking services on this one. Now, Branchless Banking is no longer under the supervision of Bank Indonesia, as effective since December 2014, the Financial Services Authority has taken over the supervision of financial institutions. Including making regulations related to the Bank's services or products Branchless Banking now has a name that varies from UPLK and now Laku Pandai branchless banking business model, which was launched in 2013 there were three namely: Bank Led, Led Telco, Hybrid is a combination of both The reason why Bank Indonesia at that time allowed Implementation of virtual banks based on the concept of telcoled model and led model bank in order to encourage competition, thus providing low cost for lower class society. If only using telco-led, telko company can only provide money transfer services. While the model of the led bank is welcome to give service collection of third-party funds and transfers. Telco led model is the implementation of branchless banking 
initiated by Telco company. The Bank acts as a supporter or not at all using bank services. The weakness of this model is that customers' funds do not earn interest and are not guaranteed by the deposit insurance agency. While the led model bank, the bank became the initiator by utilizing the telecommunications industry and agent banking. The advantage of this model is that the customer model is better protected because the bank implements the risk management, besides the customers can enjoy all banking products. Interviews with informants said that the current approved business model is Bank Led, which is the bank responsible for conducting banking services activities from the beginning to the end.

Branchless Banking Program or Non-Office Finance Service In the Framework of Inclusive Finance (Branchless Banking) allows banks to expand business by relying on agents. Agents play an important role for banks when they expand, and banks do not have to pay agents like bank employees. Agents are only paid on a commission per transaction system. With the banking in Indonesia to reduce its operational costs in the framework of business expansion. The banking agents themselves are 3, passive banking agents and active banking agents and there are also pro-active banking agents such as those implemented by BTPN Bank.

In the Branchless Banking ecosystem, agents play a very important role, because agents are the spearhead where customers perform banking transactions. The agent may be a legal entity or individual, selected based on certain criteria such as track record of business, reputation, location, and ability and knowledge of potential agents. So far there are no problems related to branchless banking. OJK requires an organizing bank to implement risk management, in order to avoid unwanted things for banking agents. There is not much difference between the requirements before being taken over by OJK or later.

Branchless banking users, without the need to deposit any money, you can register yourself to become its customers. Also, more practical, customers do not have to bother memorizing the account number, just with your active mobile number, because the mobile number will automatically become the account number. People do not be afraid to forget, very easy and fast. Certainly can do any financial transactions, without having to go to the Bank to register and without fear of not having the funds. The public does not need to be tired for long waiting in the Bank to conduct financial transactions, because the service process is very fast.

\section{A. Conclusion}

The presence of Branchless Banking is not so well known by the people of Medan, only about $21.9 \%$ of people who know Branchless banking Agent banking agents are particularly pro-active to "pick up the ball" to the community to help open an account, funds transfer, deposit or withdrawal savings, In order to speed up the government's objectives. Currently, only 4 Banks are approved by the Financial Services Authority to conduct Branchless Banking namely: Bank Mandiri, BRI, BTPN, and BCA. The government is too early to force this service launched, given the many people who do not know the service in. Although if viewed from the side of the media into one of the tools to be used in transactions. The Branchless Banking Regulation has been taken over by the Financial Services Authority since December 2014, replacing BI's BI regulation. The business model currently implemented is Bank Led, which is the bank responsible for carrying out banking services from beginning to end, Telecommunication networks are a problem for banking agents, resulting in slow transactions in doing business so that taking a long time in making transactions makes customers and banking agents feel less comfortable.

\section{REFERENCES}

[1] Yenny Purwati, et.al, "Strategi PPeningkatan Kemampuan Adopsi Teknologi Branchless Banikng untuk Memperluas Inklusi Keuangan di Masyarakat", hlm. 205, 2004.

[2] Yusharto, Irma, "Branchless Banking sebagai Terobosan Inklusi Finansial" (Tulisan untuk memperkaya perbankan di Indonesia). Dikutip dari academia.edu (Online) https://www.academia.edu, 2014.

[3] Timothy R. Lyman, Gautam Ivatury, Stefan Staschen. "Use of Agnets in Branchless Banking for The Poor: Rewards, Risks, and Regulation". the Consultative Group to Assist the Poor. No.38, 2006.

[4] Khanan, "Appek Yuridis Keberadaan Agen dalam Model Branchless Banking di Sistem PPerbaikan Indonesia"Privat Law, Vol. IV No. 1, Januari-Juni 2016.

[5] Gautam Ivatury, Ignacio Mas. "The Early Experience with Branchless Banking”. The Social Science Research Network. No 46, April 2008.

[6] Luiz Moutinho, Anne Smith, "Modelling Bank Customer Satisfaction Through Mediation of Attitudes Towards Human and Automated Banking". International Journal of Bank Marketing. Vol. 18 Iss 3, 2000.

[7] Bank Indonesia, "Peraturan Bank Indonesia Nomor: 14/2/PBI/2012 tentang Perubahan atas PBI Nomor:11/11/PBI/2009 tentang Kegiatan Alat Pembayaran dengan Menggunakan Kartu”, 2012.

[8] Hidayat Syah, "Penelitian Deskriptif" Jakarta: Rajawali, 2010.

[9] Moleong, "Metodologi Penelitian Kualitatif', PT. Remaja Rosdakarya, Bandung 1991.

[10] Herdiansyah, haris, "Metodologi Penelitian Kuantitatif", Jakarta: Salemba Humanika, 2010.

[11] Silalahi, Ulber, "Metode Penelitian Sosial", Bandung : Unpar Press, 2006.

[12] Bogdan, R.C dan Biklen, S.K, "Qualitative Research For Education : An Introduction to Theory and Mehtods, Boston : Allyn and Bacon, Inc, 1982.

[13] Syukur Kholil, "Metodologi penelitian", Bandung : Cipta Pusaka Media, 2006. 